\title{
DETERMINAN YANG MEMPENGARUHI KASUS PERCERAIAN DI HUBUNGKAN DENGAN PASAL 116 KOMPILASI HUKUM ISLAM (STUDI KASUS PENGADILAN AGAMA KARAWANG PERIODE 2017-2018)
}

\author{
Sartika Dewi \\ Universitas Buana Perjuangan Karawang \\ sartikadewi@ubpkarawang.ac.id \\ DOI : https://doi.org/ 10.29313/shjih.v18i1.6088
}

\begin{abstract}
ABSTRAK
Menurut Pasal 207 KUHPerdata perceraian merupakan penghapusan perkawinan dengan putusan hakim, atas tuntutan salah satu pihak dalam perkawinan itu berdasarkan alasan-alasan yang tersebut dalam undang-undang. Tujuan ideal perkawinan baik menurut hukum nasional (Undang-Undang No.1 Tahun 1974), hukum Islam dan hukum adat adalah untuk membentuk keluarga yang bahagia, kekal dan abadi akan tetapi dalam realitanya sulit sekali untuk diwujudkan. Hal ini dikarenakan adanya faktor-faktor yang mempengaruhi kehidupan berumah tangga baik itu secara internal maupun eksternal. Tujuan penelitian ini adalah untuk mengetahui faktorfaktor yang mempengaruhi perceraian dan faktor dominan yang mempengaruhi perceraian. Metode yang digunakan dalam penelitian ini adalah Penelitian kualitatif yaitu dilaksanakan untuk membangun pengetahuan melalui pemahaman dan penemuan. Pendekatan penelitian kualitatif adalah suatu proses penelitian dan pemahaman yang berdasarkan pada masalah manusia. Hasil penelitian ini menjelaskan bahwa Faktor-faktor yang mempengaruhi perceraian dilingkungan Pengadilan Agama Karawang Periode 2017-2018 diantarnya: meninggalkan salah satu pihak, perselisihan terus menerus, ekonomi dan tidak ada keharmonisan. Sedangkan untuk faktor dominanya adalah perselisihan terus menerus. Melihat faktor perceraian yang ada maka pendalaman nilai agama serta pemaksimalan peran orang tua dalam pemberian nasihat pra-nikah tentang pernikahan dan keluarga yang sakinah mawaddah warahmah bagi pasangan yang akan menikah agar meminimalisir terjadi perceraian dalam perkawinan.
\end{abstract}

Kata Kunci: Faktor, Perkawinan, Perceraian, KHI, Pengadilan Agama.

\section{ABSTRACT}

According to Article 207 of the Civil Code divorce is the abolition of marriage by a judge's decision, on the demands of one party in the marriage based on the reasons stated in the law. The ideal goal of marriage according to national 
law (Law No. 1 of 1974), Islamic law and customary law is to form a happy, eternal and eternal family but in reality it is very difficult to realize. This is due to the factors that affect household life both internally and externally. The purpose of this study was to determine the factors that influence divorce and the dominant factors that influence divorce. The method used in this study is qualitative research that is carried out to build knowledge through understanding and discovery. A qualitative research approach is a process of research and understanding based on human problems. The results of this study explain that the factors affecting divorce in the Karawang Religious Court in the 2017-2018 Period were: leaving one party, continuous disputes, economic and no harmony. Whereas the dominance factor is continuous disputes. Seeing the existing divorce factors, the deepening of religious values and maximizing the role of parents in providing pre-marital advice about marriage and families who are confident of warahmah for couples who are going to get married in order to minimize the occurrence of divorce in marriage.

Keywords: Factors, Marriage, Divorce, KHI, Religious Courts. Factors, Marriage, Divorce, KHI, Religious Courts.

\section{A. PENDAHULUAN}

\section{Latar Belakang Masalah}

Menurut kamus besar bahasa Indonesia (KBBI) pengertian dari Determinan adalah Faktor yang menentukan, hal (keadaan, peristiwa) yang ikut menyebabkan (mempengaruhi) terjadinya sesuatu. Determinan/ faktor yang dimaksud dalam penelitian ini adalah faktor-faktor yang mempengaruhi perceraian.

Perceraian adalah ketakutan setiap pasangan yang telah berumah tangga maupun ingin menuju ke jenjang tersebut. Penelitian menyatakan bahwa faktor penyebab terbesar perceraian adalah kondisi ekonomi. Namun sebelum menyentuh masalah di faktor tersebut, ternyata ada beberapa faktor lain yang mampu melatarbelakangi terjadinya perceraian. Beberapa faktor penyebab perceraian tersebut diketahui sebagai faktor terbesar yang diambil dari hasil rata-rata di berbagai penjuru dunia. Dilansir dari sciencealert, 6 faktor di antaranya adalah:

a. Menikah di usia remaja atau lebih diusia 35 tahun.

b. Suami tidak bekerja full-time atau bahkan tidak bekerja. 
c. Semakin rendah tingkat pendidikan, semakin besar tingkat perceraian.

d. Sering merendahkan atau meremehkan pasangan.

e. Tidak dapat menyelesaikan permasalahan ketika terjadi perdebatan bahkan cenderung lari dari permasalahan tersebut.

f. Sering mendeskrifsikan pasangan dalam sudut yang negatif. ${ }^{1}$

Dengan adanya UndangUndang No.1 tahun 1974 tentang perkawinan, dan berlakunya secara efektif sejak tanggal 1 Oktober 1975 tentang pelaksanaan undang-Undang No.1 tahun 1974 tentang perkawinan. yang mana dalam pasal 1 UndangUndang No.1 Tahun 1974 yang berbunyi : "perkawinan ialah ikatan lahir batin antara seorang pria dengan seorang wanita sebagai suami istri dengan tujuan membentuk keluarga (rumah tangga) yang bahagia dan kekal berdasarkan Ketuhanan Yang Maha Esa". ${ }^{2}$

Menurut Wirjono Projodikoro, perkawinan adalah hidup bersama dari seorang laki - laki dan seorang perempuan yang memenuhi syarat - syarat tertentu. Kedewasaan dalam hal fisik dan rohani dalam perkawinan adalah merupakan dasar untuk mencapai tujuan dan cita-cita perkawinan, walaupaun demikian masih banyak juga anggota masyarakat kita yang kurang memperhatikan atau menyadarinya. ${ }^{3}$

Perkawinan menurut Hukum Islam adalah pernikahan, yaitu akad yang sangat kuat atau mistaqan qhalidzan untuk mentaati perintah Allah dan melaksanakan merupakan ibadah". Hukum Islam perkawinan adalah akad atau persetujuan antara calon suami dan calon istri karenanya berlangsung melalui ijab dan qobul atau serah terima. Apabila akad nikah tersebut telah dilangsungkan, maka

${ }^{1}$ https://www.idntimes.com/science/experiment/bayu/faktor-penyebab-perceraian/full

2.Subekti,,Kitab Undang-Undang Hukum Perdata,Pradnya Paramita, Jakarta, 2004, hal.537

${ }^{3}$ Wirjono Projodikoro, hukum perkawinan di Indonesia,cetakan keenam, hal 7 
mereka telah berjanji dan bersedia menciptakan rumah-tangga yang harmonis, akan hidup semati dalam menjalani rumah-tangga bersamasama. ${ }^{4}$

Perceraian yang sering ditemui dalam kehidupan masyarakat merupakan momok yang ditakuti karena dampaknya bukan saja bagi suami istri melainkan juga terhapap anak-anak dan keluarga kedua belah pihak, karena dengan terjadinya perceraian akan menimbulkan akibat-akibat hukum terhadap perceraian tersebut, maka untuk tanggung jawab orang tua pasca perceraian untuk biaya-biaya hidup, pendidikan, dan kesehatan akan menjadi suatu permasalahan hukum. Hal ini dapat dilihat dari berita-berita media masa dan semakin banyaknya perkara perceraian yang diselesaikan oleh pengadilan. ${ }^{5}$ Antara suami istri sering terjadi perselisihan atau pertengkaran yang terus menerus sehingga dapat menimbulkan suatu keadaan yang menyebabkan perceraian, sedangkan upaya-upaya damai yang dilakukan oleh kedua belah pihak maupun keluarga tidak membawakan hasil yang maksimal sehingga pada akhirnya jalan keluar yang harus ditempuh tidak lain adalah perceraian. Perceraian selama ini seringkali menyisakan problem-problem, terutama persoalan hak-hak anak yang mencakup seluruh hak yang melekat pada anak yaitu hak memperoleh pendidkan, kesehatan, biaya pemeliharaan dan lain sebagainya.

Perceraian merupakan putusan ikatan perkawinan atas kehendak suami atau istri atau kehendak keduanya yang dapat bersumber dari tidak terlaksana hak-hak dan kewajiban-kewajiban sebegaimana seharusnya menurut hukum perkawinan

\footnotetext{
${ }^{4}$ Departemen Agama RI, Kompilasai Hukum Islam di Indonesia. Direktorat Jendral Pembinaan Kelembagaan Agama, Jakarta, 2000, hal. 14.

5 Tan Kamello dan Syarifah lisa Andriati, Hukum Orang dan Keluarga, USU Press, Medan, 2011, hal.79
} 
yang berlaku. Perceraian dipilih sebagai solusi terakhir oleh para pihak dalam menyelesaikan permasalahan rumah tangga. ${ }^{6}$

Menurut data yang dilansir oleh Badan Pusat Statistik (BPS) dalam “Statistik Indonesia 2018', sebuah publikasi kompilasi data statistik tahunan di Indonesia, jumlah seluruh kasus perceraian yang terjadi di Indonesia pada tahun 2018 adalah sebanyak 374.516 kasus perceraian. Hal tersebut sudah seharusnya menjadi peringatan bagi kita semua. Jika dibandingkan dengan tahun-tahun sebelumnya maka didapatkan suatu kenaikan yang cukup stabil. Jumlah seluruh kasus perceraian di Indonesia pada tahun 2016 adalah 365.654 kasus perceraian. Sementara jumlah seluruh kasus perceraian di Indonesia pada tahun 2015 adalah 353.843 kasus perceraian. Lebih lanjut, jika dibuat perhitungan presentase laju kenaikan kasus perceraian di Indonesia setiap tahunnya, maka didapatkan bahwa terjadi kenaikan sebesar 11.811 kasus perceraian atau 3,33\% dari tahun 2015 ke tahun 2016. Sementara kenaikan pada tahun 2016 ke tahun 2017 adalah sebesar 8.862 kasus perceraian atau 2,42\%. Data yang dimiliki oleh BPS tersebut, khususnya pada data tahun 2017, tampak sesuai dengan jumlah cerai talak dan cerai gugat pada data milik Direktorat Jenderal Badan Peradilan Agama (Dirjen Badilag) Mahkamah Agung pada tahun yang sama.

Data Perceraian per Provinsi di Indonesia Jumlah perceraian di Indonesia setiap provinsi bervariasi. Berdasarkan data yang dilansir oleh BPS dalam 'Statistik Indonesia 2018', maka Provinsi Jawa Timur (87.475 kasus), Provinsi Jawa Barat (79.047 kasus), dan Provinsi Jawa Tengah (69.857 kasus) menempati urutan pertama, kedua, dan ketiga dalam hal jumlah kasus perceraian terbanyak di Indonesia pada tahun 2017.

Jawa Timur secara konsisten menempati urutan pertama jumlah kasus perceraian di Indonesia selama tiga tahun terakhir, dengan jumlah kasus perceraian

${ }^{6}$ Ummul khaira, pelaksanaan upaya perdamaian dalam perkara perceraian,. FH Universitas Syiah Kuala. Jurnal Penelitian Hukum De Jure Vol.18, No 3. (2018). 
sebanyak: 87.475 kasus (tahun 2015); 86.491 kasus (tahun 2016); dan 84.839 kasus (tahun 2017). Sementara Jawa Barat dan Jawa Tengah saling berganti urutan antara kedua dan ketiga dalam jumlah kasus perceraian terbanyak di Indonesia selama tiga tahun terakhir. Jawa Barat memiliki jumlah kasus perceraian sebanyak: 70.293 kasus (tahun 2015); 75.001 kasus (tahun 2016); dan 79.047 kasus (tahun 2017). Sementara Jawa Tengah memiliki jumlah kasus perceraian sebanyak: 71.901 kasus (tahun 2015); 71373 kasus (tahun 2016); dan 69.857 kasus (tahun 2017). ${ }^{7}$

Kasus perceraian di Jawa Barat mengalami peningkatan, Selain itu kasus perceraian yang terus meningkat disebabkan kesiapan mental yang kurang siap dalam menempuh status pernikahan. "Jika dilihat dari statistik tahunan, tahun 2018 tingkat perceraian meningkat," sebanyak 24.793 pasangan di tahun 2018 bercerai karena cerai talak dan sebanyak 70.733 orang pasangan menggugat cerai. Sedangkan di tahun 2017 sebanyak 23.173 orang melakukan cerai talak dan 64.907 pasangan menggugat cerai pasangannya masing-masing. Total angka perceraian sebanyak 95.526 orang pasangan melakukan perceraian di tahun 2018 . Sebanyak 88.080 orang melakukan perceraian di tahun $2017 .{ }^{8}$ Sedangkan kasus perceraian yang terjadi di Kabupaten Karawang terhitung dari bulan januari - Juli 2019 tercatat sebanyak 2.200 perkara perceraian.

\section{Identfifikasi Masalah}

Artikel ini akan membahasa masalah tentang Determinan apa saja yang mempengaruhi perceraian di Pengadilan Agama Karawang Periode 2017-2018 baik determinan secara umum dan determinan yang mendominasi dari terjadinya perceraian di Kabupaten Karawang.

\section{Metode Penelitian}

${ }^{7}$ https://www.bps.go.id/linkTableDinamis/view/id/893 (5/8/19. 12:23)

${ }^{8}$ https://jabarnews.com/read/70157/kasus-perceraian-di-jawa-barat-meningkat (5/8/19. 12:30) 
Penelitian ini menggunakan metode, Penelitian kualitatif dilaksanakan untuk membangun pengetahuan melalui suatu proses penelitian dan pemahaman yang berdasarkan pada masalah manusia. ${ }^{9}$ Pendekatan secara Yuridis Normatif, yaitu pendekatan yang berasal dari Peraturan Perundang-undangan (Statute Aprroach). Dalam penelitian karya ilmiah dapat menggunakan salah satu dari tiga bagian metode yaitu library research, ialah karya ilmiah yang didasarkan pada literatur atau pustaka; field research, yaitu penelitian yang didasarkan pada penelitian lapangan; dan bibliographic research, yaitu penelitian yang memfokuskan pada gagasan yang terkandung dalam teori ${ }^{10}$ Penelitian hukum semacam ini tidak mengenal penelitian lapangan (field research) karena yang diteliti adalah bahanbahan hukum sehingga dapat dikatakan sebagai library based, focusing on reading and analysis of the primary and secondary materials ${ }^{11}$ (berbasis perpustakaan, berfokus pada membaca dan menganalisis bahan-bahan primer dan sekunder). Spesifikasi penelitian ini adalah deskriptif analitis. Penelitian deskriptif analitis menggambarkan realitas yang berkaitan dengan perlindungan hak moral pencipta, untuk kemudian dianalisis berdasarkan peraturan perundang-undangan yang berlaku.

\section{B. PEMBAHASAN}

\section{Determinan Yang Mempengaruhi Perceraian di Pengadilan Agama} Karawang Periode 2017-2018 di Hubungkan Dengan Pasal 116 KHI

Perkawinan menurut Sujuti Thalib, adalah perjanjian suci membentuk keluarga antara seorang laki-laki dengan seorang perempuan. Unsur perjanjian di sini untuk pemperlihatkan segi kesengajaan diri perkawinan serta menampakkannya pada

\footnotetext{
${ }^{9}$ Iskandar, Metodologi Penelitian Kualitatif, Gaung Persada , cet.1, Jakarta, 2009, hlm.11

${ }^{10}$ Soerjono Soekanto dan Sri Mamudji, Penelitian Hukum Normatif Tinjauan Singkat, Rajawali Pers, Jakarta, 2006, hlm. 23.

${ }^{11}$ Honny Ibrahim, Teori dan Metodologi Penelitian Hukum Normatif, Bayumedia Publishing, Malang, 2006, hlm. 46.
} 
masyarakat ramai. Sedangkan sebutan suci untuk pernyataan segi keagamaannya dari suatu perkawinan ${ }^{12}$. Telah dijelaskan dalam UU No 1 tahun 1974 bahwa tujuan perkawinan adalah untuk keluarga atau rumah tangga yang bahagia dan kekal, sehingga sangatlah jelas bahwa UU No 1 tahun 1974 tidak mengehndaki terjadinya perceraian. Namun di dalam pasal 38 dijelaskan bahwa perkawinan dapat putus karena kematian, perceraian dan atas putusan pengadilan. Putusnya perkawina atas putusan pengadilan adalah putusnya perkawinan karena gugatan seorang istri yang melangsungan perkawinan menurut agama Islam, atau karena gugatan seorang suami atau sitri yang melangsungkan perkawinan menurut agama dan keprcayaan bukan islam, dan gugatan tersebut dikabulkan oleh pengadilan dengan suatu keputusan. ${ }^{13}$

Perinsipnya, seorang pria dengan seorang wanita yang mengikat lahir dan batinya dalam suatu perkawinan tersebut dengan cara perceraian berdasarkan hukum perceraian yang berlaku. Namun suami dan istri yang akan melakukan perceraian harus mempunyai alasan-alasan hukum tertentu dan perceraian itu harus di depan sidang Pengadilan setelah Pengadilan yang bersangkutan terus berusaha dan tidak berhasil mendamaikan kedua belah pihak sebagaimana diatur dalam Pasal 39 UU No. 1 Tahun 1974.

Dalam UU No. 1 Tahun 1974, ditegaskan bahwa yang dimaksud dengan perceraian adalah: "Terlepasnya ikatan perkawinan antara kedua belah pihak, setelah putusan pengadilan mempunyai kekuatan hukum yang tetap berlaku sejak berlangsungnya perkawinan". Masalah perceraian dalam UndangUndang No. 1 Thn 1974, diatur dalam pasal-pasal berikut: Pasal 38 bahwa Perkawinan dapat putus karena: Kematian; Perceraian; Atas putusan pengadilan. Pasal 39, Perceraian hanya dapat dilakukan di depan sidang pengadilan yang bersangkutan berusaha dan tidak

\footnotetext{
${ }^{12}$ Sujuti Talib, Hukum Kekeluargaan Indonesia, Universitas Indonesia press, Jakarta, 1982, hlm.47.

${ }^{13}$ Dian Ety Mayasari, tinjauan yuridis adanya KDRT sebagai alasan untuk melakukan perceraian" MIMBAR HUKUM jurnal.ugm.ac.id Vol 25, No 3 (2013)
} 
berhasil mendamaikan kedua belah pihak; Untuk melakukan perceraian harus ada alasan, bahwa antara suami/istri itu tidak dapat hidup rukun sebagai suami istri; Tata cara perceraian di depan sidang pengadilan di atur dalam peraturan perundangundangan sendiri; Pasal 40, Gugatan perceraian diajukan kepada pengadilan; Tata cara mengajukan gugatan tersebut pada ayat (1) Pasal ini diatur dalam perundang-undangan tersendiri.

Dari pendapat di atas dapat disimpulkan bahwa yang dimaksud dengan perceraian adalah putusnya ikatan perkawinan antara seorang pria dan seorang wanita sebagai suami istri dan setelah putusan pengadilan mempunyai kekuatan hukum yang tetap berlaku sejak berlangsungnya perkawinan. Permasalahan didalam rumah tangga sering kali terjadi, dan memang sudah menjadi bagian dalam lika-liku kehidupan didalam rumah tangga, dan dari sini dapat diketahui kasus "perceraian" yang kerap kali menjadi masalah dalam rumah tangga. Pada dasarnya faktor yang menyebabkan terjadinya perceraian sangat unik dan kompleks dan masing-masing keluarga berbeda satu dengan lainnya. Adapun faktor-faktor yang mengakibatkan perceraian dalam rumah tangga yang terdapat dilingkungan Pengadilan Agama Karawang periode 2017-2018 dapat penulis kemukakan adalah:
a. Meninggalkan salah satu pihak
b. Perselisihan terus menerus,
c. Faktor ekonomi dan
d. Tidak ada keharmonisan dalam Rumah tangga.

Untuk lebih detail nya penulis gambarkan secara diagram dibawah ini: 

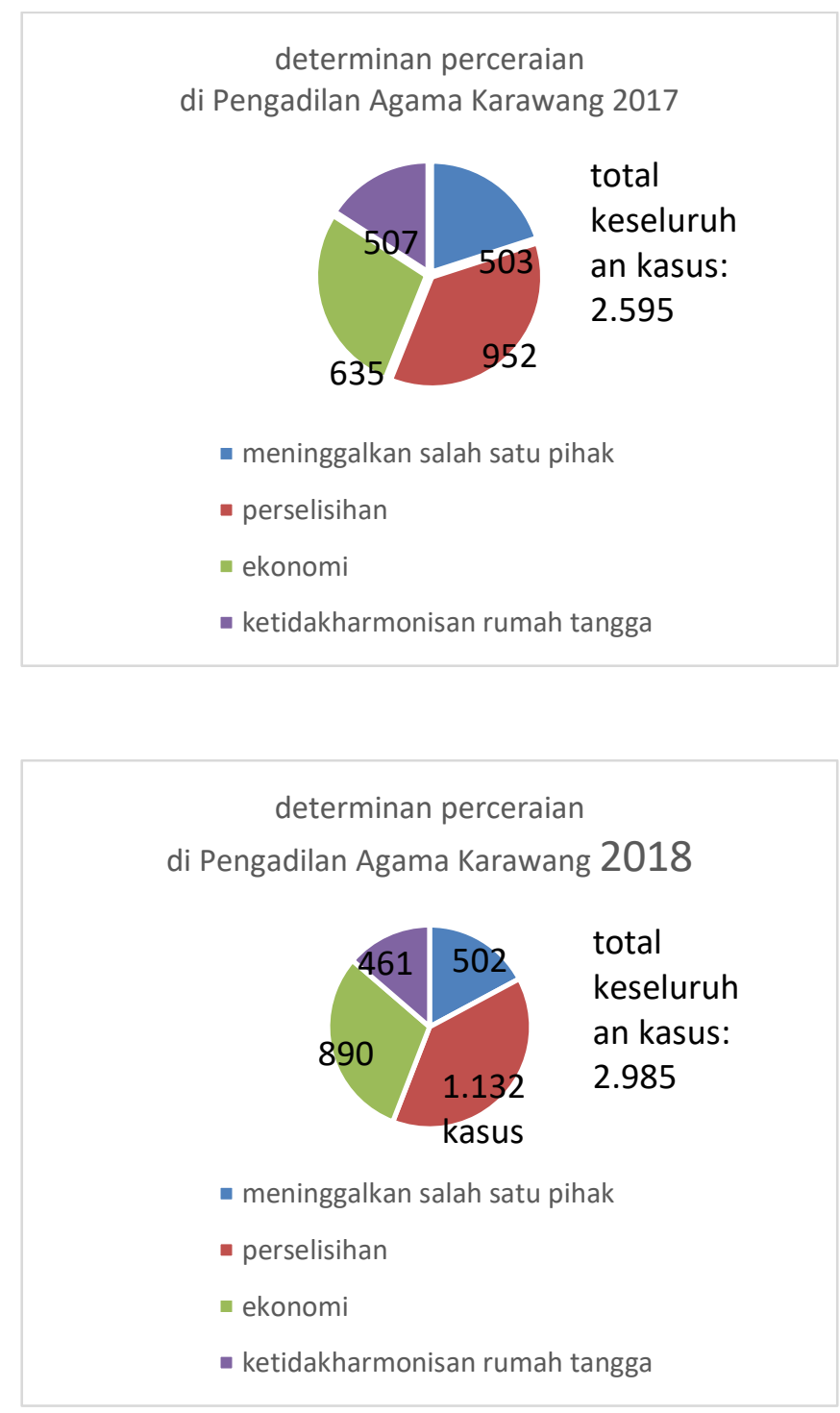

Indonesia adalah Negara berketuhanan yang mana adanya unsur religientitas kepercayaan terhadap Tuhan Yang Maha Esa. Sejalan dengan hal tersebut dalam hukum perkawinan unsur agama sangatlah kuat, baik dari Undang-Undang Nomor 1 Tahun $\underline{1974}$ tentang Perkawinan maupun Kompilasi Hukum Islam sebagaimana keberlakunya melalui Instruksi Presiden Republik Indonesia Nomor 1 Tahun 1991 tentang Penyebarluasan Kompilasi Hukum Islam. Ikatan perkawinan adalah sesuatu yang sakral dan bukan suatu hal yang dapat dengan mudah untuk melepaskan ikatan perkawinan tersebut. Mengingat sucinya lembaga perkawinan seharusnya 
perceraian merupakan upaya terakhir yang dapat diambil oleh pasangan suami istri. Menurut UU No 1 Tahun 1974 tentang Perkawinan diatur perkawinan dapat putus karena: Kematian, Perceraian dan atas keputusan Pengadilan. Pasal 39 UU Perkawinan mengatur bahwa perceraian hanya dapat dilakukan di depan Sidang Pengadilan setelah Pengadilan yang bersangkutan berusaha dan tidak berhasil mendamaikan kedua belah pihak. Selain itu harus ada cukup alasan bahwa antara suami istri itu tidak akan dapat rukun lagi sebagai suami isteri.

Pasal 19 PP No 9 Tahun $\underline{1975}$ tentang Pelaksanaan UU No 1 Tahun 1974 tentang Perkawinan perceraian dapat terjadi karena alasan atau alasan-alasan:

a. Salah satu pihak berbuat zina atau menjadi pemabok, pemadat, penjudi, dan lain sebagainya yang sukar disembuhkan;

b. Salah satu pihak meninggalkan pihak lain selama 2 (dua) tahun berturutturut tanpa izin pihak lain dan tanpa alasan yang sah atau karena hal lain diluar kemampuannya;

c. Salah satu pihak mendapat hukuman penjara 5 (lima) tahun atau hukuman yang lebih berat setelah perkawinan berlangsung;

d. Salah satu pihak melakukan kekejaman atau penganiayaan berat yang membahayakan pihak yang lain;

e. Salah satu pihak mendapat cacat badan atau penyakit dengan akibat tidak dapat menjalankan kewajibannya sebagai suami/isteri;

f. Antara suami dan isteri terus-menerus terjadi perselisihan dan pertengkaran dan tidak ada harapan akan hidup rukun lagi dalam rumah tangga.

\section{Selanjutnya Pasal 20 PP No 9 Tahun 1975 diatur bahwa:}

a. Gugatan perceraian diajukan oleh suami atau isteri atau kuasanya kepada Pengadilan yang daerah hukumnya meliputi tempat kediaman tergugat.

b. Dalam hal tempat kediaman tergugat tidak jelas atau tidak diketahui atau tidak mempunyai tempat kediaman yang tetap, gugatan perceraian diajukan kepada Pengadilan di tempat kediaman penggugat. 
c. Dalam hal tergugat bertempat kediaman di luar negeri, gugatan perceraian diajukan kepada Pengadilan di tempat kediaman penggugat. Ketua Pengadilan menyampaikan permohonan tersebut kepada tergugat melalui Perwakilan Republik Indonesia setempat.

\section{Lebih lanjut Pasal 21 PP No 9 Tahun 1975 diatur bahwa:}

a. Gugatan perceraian karena alasan tersebut dalam Pasal 19 huruf b, diajukan kepada Pengadilan di tempat kediaman penggugat.

b. Gugatan tersebut dalam ayat (1) dapat diajukan setelah lampau 2 (dua) tahun terhitung sejak tergugat meninggalkan rumah.

c. Gugatan dapat diterima apabila tergugat menyatakan atau menunjukkan sikap tidak mau lagi kembali ke rumah kediaman bersama.

Pengaturan dalam UU Perkawinan dan PP No 9 Tahun $\underline{1975}$ sama dengan yang diatur dalam Kompilasi Hukum Islam (KHI). Pada Pasal 116 KHI diatur bahwa perceraian dapat terjadi karena alasan atau alasan-alasan :

a. Salah satu pihak berbuat zina atau menjadi pemabuk, pemadat, penjudi dan lain sebagainya yang sukar disembuhkan;

b. Salah satu pihak mninggalkan pihak lain selama 2 (dua) tahun berturut-turut tanpa izin pihak lain dan tanpa alasan yang sah atau karena hal lain diluar kemampuannya;

c. Salah satu pihak mendapat hukuman penjara 5 (lima) tahun atau hukuman yang lebih berat setelah perkawinan berlangsung;

d. Salah satu pihak melakukan kekejaman atau penganiayaan berat yang membahayakan pihak lain;

e. Salah satu pihak mendapat cacat badab atau penyakit dengan akibat tidak dapat menjalankan kewajibannya sebagai suami atau istri

f. Antara suami dan istri terus menerus terjadi perselisihan dan pertengkaran dan tidak ada harapan akan hidup rukun lagi dalam rumah tangga;

g. Suami melanggar taklik talak; 
h. Peralihan agama atau murtad yang menyebabkan terjadinya ketidak rukunan dalam rumah tangga.

\section{Pasal 133 KHI :}

a. Gugatan perceraian karena alasan tersebut dalam pasal $\underline{116}$ huruf $\mathrm{b}$, dapat diajukan setelah lampau 2 (dua) tahun terhitung sejak tergugat meninggalkan gugatan meninggalkan rumah.

b. Gugatan dapat diterima apabila tergugat menyatakan atau menunjukkan sikap tidak mau lagi kembali ke rumah kediaman bersama.

c. Berdasar pada ketentuan hukum tersebut dapat disimpulkan bahwa untuk melakukan gugatan cerai hanya dapat dilakukan setelah pihak suami meninggalkan isteri selama 2 (dua) tahun berturut-turut tanpa izin.

Perselisihan dan pertengkaran secara terus-menerus yang termuat dalam pasal $\underline{116}$ huruf $\mathrm{f}$ saat ini menjadi salah satu alasan perceraian yang banyak digunakan. Batasan mengenai perselisihan dan pertengkaran tersebut belumlah jelas sehingga dikhwatirkan dengan belum ada batasan mengenai pasal tersebut maka digunakan sebagai batu loncatan untuk menceraikan pasanganya. Terlebih lagi jika perselisihan dan pertengkaran secara terus-menerus ini digunakan sebagai alasan perceraian yang mana pada kenyataanya permasalahan atau perselisihan yang di hadapi pasangan suami istri dirasa masih dapat diselesaikan tanpa harus adanya perceraian. Kompilasi Hukum Islam bersumber dari Hukum Islam, dalam hukum Islam perselisihan dan pertengkaran secara terus-menerus dikenal dengan istilah syiqaq (Perselisihan/retaknya hubungan), sehingga untuk menentukan lebih lanjut mengenai batasan perselisihan dan pertengkaran secarara terus-menerus penting untuk mengetahui syiqaq terlebih dahulu. Hasil penelitian batasan alasan perceraian karena perselisihan dan pertengkaran secara terus-menerus yang termuat dalam pasal 116 huruf $\mathrm{f}$ adalah dalam rumah tangga tidak ada ketentraman yang disebabkan perbuatan atau perkataan seperti mencaci dengan kata-kata kotor dan kasar, mencela kehormatan, memukul dengan maksud melukai, menganjurkan atas perbuatan yang di benci oleh Allah SWT, berpisah ranjang tanpa adanya sebab yang 
memperbolehkanya, serta antara suami dan istri sudah saling mengabaikan hak dan kewajiban masing-masing. Dalam perselisihan dan pertengkara secara terusmenerus antara suami istri diwajibkan pengankatan hakam sebagai mediator/arbitror yang menjadi penegah diantara mereka. ${ }^{14}$

Tujuan perkawinan adalah hidup bersama dalam keadaan tentram dan damai. Jika perselisihan sedemikian hebat dan sering terjadi hingga keadaan tidak dapat baik lagi, maka sangat layak apabila ada perceraian, oleh karena tujuan utama perkawinan yaitu hidup bersama secara memuaskan, ternyata tidak tercapai. Hanya saja yang perlu di camkan, bahwa harus betul-betul perselisihan yang hebat dan sering itu. Untuk itu hakim di depan sidang pengadilan yang akan menetapkan ada atau tidak adanya perselisihan harus mendengarkan keterangan dari pihak yang menuntut perceraian dan seberapa boleh juga dari pihak yang lain dan orang-orang keluarga atau teman sahabat karibnya dari suami dan istri. Dengan demikian, dapat diusahakan agar hakim dapat mengetahui sungguh-sungguh keadaan yang sebenarnya dalam rumah tangga suami dan istri yang mengajukan perceraian tersebut. $^{15}$

Salah satu masalah utama yang sering dihadapi suami istri, adalah kebutuhan ekonomi dalam rumah tangga, ketidakmampuan suami memenuhi kebutuhan ekonomi itu akan menyebabkan ketidakharmonisan suami istri yang mudah memicu terjadinya perceraian. Ketidakharmonisan kehidupan suami istri dalam rumah tangga antara lain dipicu oleh ketidakseimbangan dalam hubungan suami istri. Menurut DeVito dalam equtiy theory (teori keseimbangan), bahwa dalam sebuah hubungan, keseimbangan sangat dibutuhkan untuk mempertahankan

\footnotetext{
${ }^{14}$ Elsa Cholidatul Nikmah "batasan alasan perceraian karena perselisihan dan pertengkaran secara terus menerus (studi pasal 116 huruf F kompilasi hukum islam)" hukum student journal 2018. ${ }^{15}$ M. Rampto laguni “ tinjauan yuridis terhadap perselisihan terus menerus sebagai penyebab terjadinya perceraian (studi putusan Pengadilan Agama Palu Bo 334/Pdt.G/2013/PA.PAL)" jurnal ilmu hukum Legal Opinion edisi 6, Vol 1 (2013)
} 
hubungan. Keseimbangan di sini tidak hanya berupa materi, namun dapat juga berupa perhatian, pengorbanan dan pembagian tugas dalam hubungan. Jika keseimbangan tidak terwujud, maka keutuhan hubungan dapat terancam. Salah satu masalah utama yang sering dihadapi dalam suatu hubungan suami istri adalah tidak adanya keseimbangan dari sisi keuangan. Apalagi hampir semua kalangan menempatkan masalah keuangan ini sebagai masalah yang besar. Masalah ekonomi ini dapat terjadi juga dalam hubungan perkawinan, yaitu suami bekerja dan istri sebagai ibu rumah tangga.

Seiring perkembangan zaman, tidak jarang penghasilan suami tidak mampu memenuhi kebutuhan rumah tangga, sehingga istri mencari alternatif untuk bekerja membantu suami dalam mencukupi kebutuhan ekonomi keluarga. Hal itu dapat menimbulkan problematika jika penghasilan istri setelah bekerja lebih besar dibandingkan dengan penghasilan suaminya. Kondisi itu tidak jarang memicu terjadinya konflik dalam rumah tangga. Hal itu terjadi dengan adanya kecemburuan suami terhadap istrinya dari sisi ekonomi. Pada beberapa kasus kondisi tersebut dapat memicu terjadinya kekerasan dalam rumah tangga. Akibat dari masalah keuangan tersebut juga dapat memicu terjadinya perselingkuhan, baik yang dilakukan salah satu pasangan maupun kedua belah pihak, lantaran tidak adanya kesepahaman dalam menyelesaikan konflik yang mereka hadapi. Sehingga tidak sedikit yang berakhir dengan perceraian. Perkawinan menimbulkan hak dan kewajiban. Salah satu kewajiban suami kepada istri adalah kewajiban ekonomi atau nafkah materi baik untuk kebutuhan sandang, pangan maupun papan. Jika kewajiban ekonomi itu diabaikan maka akan berdampak buruk terhadap kehidupan rumah tangga. Sehingga bagi istri yang tidak sabar akan menjadikan hal itu sebagai alasan untuk menggugat cerai suaminya ke Pengadilan Agama. ${ }^{16}$

Dalam hukum Islam tidak ada keharmonisan rumah tangga disebut dengan shiqāq. Shiqāq menurut bahasa berarti perselisihan atau retak. Sedangkan

\footnotetext{
${ }^{16}$ Husin anang kabalamay “ kebutuhan ekonomi dan kaitannya dengan perceraian (studi atas cerai gugat di pengadilan Agama Ambon) jurnal IAINAMBON Vol 3 No 2 (2013).
} 
menurut istilah shiqāq berarti krisis memuncak yang terjadi antara suami-isteri sedemikian rupa, sehingga antara suami isteri terjadi pertentangan pendapat dan pertengkaran, menjadi dua pihak yang tidak mungkin dipertemukan dan kedua belah pihak tidak dapat mengatasinya. ${ }^{17}$ Didalam undang-undang perkawinan di Indonesia shiqāq merupakan salah satu alasan perceraian apabila keduanya (suamiisteri) tidak dapat didamaikan. Hal ini dapat dilihat pada pasal 19 point (f) peraturan pemerintah (PP) No: 9 tahun $\underline{1975}$ Komplikasi Hukum Islam (KHI) pasal 116 point (f) yang berbunyi, "Perceraian dapat terjadi karena alasan antara suami dan isteri terus menerus terjadi perselisihan dan pertengkaran dan tidak ada harapan akan hidup rukun lagi dalam rumah tangga."

Ketidakharmonisan yang terjadi karena sudah tidak ada kecocokan, banyak hal yang menjad penyebab menjadi tidak harmonis mulai dari faktor intern dan ekstern, ketidakharmonisan dalam rumah tangga mempunyai korelasi dengan penyebab perceraian yang lainya seperti krisis akhlak, cemburu, tidak ada tanggung jawab, dan lain sebagainya letak perbedaan diantara keduanya yaitu dalam faktor penyebab perceraian karena tidak ada keharmonisan dalam duduk perkara ada banyak faktor yang muncul sebagai penyebab perceraian sedangkan dalam krisis akhlak, cemburu, tidak ada tanggung jawab, dalam duduk perkara hanya faktor tersebut yang muncul sebagai menjadi penyebab perceraian.

Ketika proses mediasi dijalankan majlis hakim selalu berupaya menasehati, mendamaikan untuk tidak bercerai, akan tetapi belum berhasil. Karena suami/istri ketika mengajukan gugatan perceraian mempunyai pendirian yang kuat untuk menceraikan suami/istri sehingga tidak ada satupun yang bisa didamaikan. Sebagai pasangan suami istri harus memahami hak dan kewajibannya sebagai upaya membangun sebuah keluarga. Kewajiban tersebut harus dimaknai secara timbal

${ }^{17}$ Abd rahman ghazali, fiqih muamalah, prenada media, Jakrta: 2003 hlm 241. 
balik yang berarti bahwa yang menjadi kewajiban suami merupakan hak istri dan yang menjadi kewajiban istri menjadi hak suami.

Pasal 80 dan Pasal 83 Kompilasi Hukum Islam (KHI) dijelaskan apa saja yang menjadi tanggung jawab suami dan istri, antara suami dan istri mempunyai kewajiban sendiri-sendiri yang harus dijalankan dan harus dipenuhi, selain itu antara suami dan istri juga mempunyai kewajiban yang harus dijalankan bersamasama sebagai pasangan suami istri. Pasal $80 \mathrm{KHI}$ bahwa suami wajib melindungi istrinya dan memberikan segala sesuatu keperluan hidup berumah tangga sesuai dengan kemampuannya, sesuai dengan penghasilannya. Pasal 83 Kompilasi Hukum Islam menjelaskan bahwa suami mempunyai kewajiban untuk memenuhi kebutuhan istrinya sesuai dengan kemampuannya, dan Pasal 83 Kompilasi Hukum Islam menjelaskan bahwa istri mempunyai kewajiban memenuhi kebutuhan lahir dan batin kepada suami di dalam batas-batas yang dibenarkan oleh hukum Islam. Istri juga mempunyai kewajiban menyelenggarakan dan mengatur keperluan rumah tangga dan keperluan sehari-hari dengan baik. Fakta di lapangan sering kali suami ataupun istri menganggap sebelah mata terhadap hak dan kewajibanya, sehingga ketika ada masalah terjadi pertengkaran dan perselisihan yang terus-men yang sulit untuk didamaikan. mereka saling menyalahkan satu sama lain tanpa intropeksi diri, pada akhirnya keluarga menjadi tidak harmonis. ${ }^{18}$

\section{Determinan Dominan Perceraian di Pengadilan Agama Karawang Periode 2017-2018 di Hubungkan Dengan Pasal 116 KHI}

Ketika membina rumah tangga, semua orang berharap agar tetap bisa bahagia dan tidak memiliki masalah. Keluarga harmonis adalah salah satu tujuan pernikahan dalam islam. Namun terkadang sebagai seorang manusia, kita tidak luput dari kesalahan. Kesalahan yang dilakukan dalam keluarga bisa memicu terjadinya perselisihan/konflik dalam keluarga dan ini bisa berakibat fatal terutama

${ }^{18}$ Syaefullah “ tidak ada keharmonisan sebagai penyebab perkara cerai gugat di kota kediri” jurnal iainKediri Vol 1 No 1 (2017) 
jika dibiarkan berlarut-larut bahkan bisa mengakibatkan hancurnya rumah tangga dan keluarga. Beberapa masalah bisa mempengaruhi kehidupan rumah tangga dan sebaiknya baik suami maupun istri harus bisa menyikapi dengan kepala dingin. Setiap hubungan antara individu akan selalu muncul yang disebut dengan konflik, tidak terkecuali dalam hubungan keluarga. Konflik seringkali dipandang sebagai perselisihan yang bersifat permusuhan dan membuat hubungan tidak berfungsi dengan baik. Secara bahasa konflik identik dengan percekcokan, perselisihan dan pertengkaran. ${ }^{19}$ Perselisihan menjadi determinan dominan dalam penelitian ini, hal ini dapat dilihat dari diagram di bawah ini yang menunjukan dalam dua tahun berturut-turut perselisihan menjadi penyumbang terbanyak determinan dalam kasus perceraian

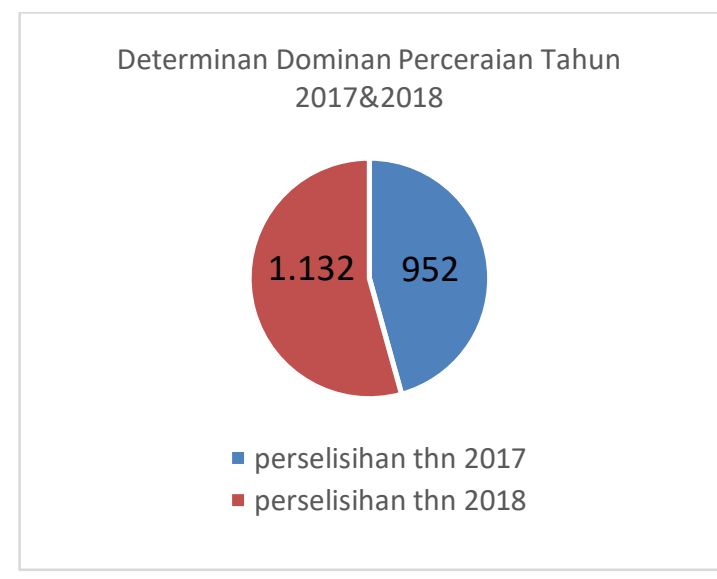

Hal ini sejalan dengan Kompilasi Hukum Islam (KHI) pada pasal 116 huruf f “Antara suami dan isteri terus menerus terjadi perselisihan dan pertengkaran dan tidak ada harapan akan hidup rukun lagi dalam rumah tangga".

Hubungan rumah tangga tidak akan selalu berjalan dengan baik dan mulus, pasti terdapat masalah-masalh yang akan timbul. Ketika suatu perkawinan diwarnai dengan adanya pertengkaran, perselisihan, atau percekcokan, merasa tidak bahagia atau masalah lainnya seringkali dijadikan alasan untuk mengakhiri perkawinan, bercerai dengan pasangan hidup dianggap sebagai jalan keluar dari persolan

${ }^{19}$ Kamus Bhs. Indonesia, 2005 
tersebut. ${ }^{20}$ Perselisihan yang terus menerus dapat mengakibatkan Konflik. Konflik mencerminkan adanya ketidakcocokan (incompatibility), baik ketidakcocokan karena berlawanan atau karena perbedaan. Sumber konflik dapat berasal dari:

a. Adanya ketimpangan alokasi sumber daya ekonomi dan kekuasaan;

b. Perbedaan nilai dan identitas;

c. Kesalahan persepsi dan komunikasi juga turut berperan dalam proses evolusi ketidakcocokan hubungan.

Konflik dapat berjalan ke arah yang positif atau negative bergantung pada ada atau tidaknya proses yang mengarah pada saling pengertian. Kondisi keluarga yang krisis dapat diartikan sebagai kondisi keluarga yang kacau, tidak teratur, tidak adanya kewibawaan orang tua dalam hal mengasuh anak, terjadinya komunikasi yang kurang efektif didalam keluarga sehingga seringkali terjadi kesalah pahaman yangkemudian terjadi pertengkaran antara ibu dan bapak atau antara orang tua dan anak. Kondisi yang demikian jika tidak segera teratasi maka akan berakibat terjadinya perceraian Ada beberapa faktor yang dapat menimbulkan terjadinya krisis keluarga sebagaimana dikatakan Sofyan Wilis (2009) antara lain: putusnya komunikasi diantara keluarga terutama ayah dan ibu, sikap egosentrisme, masalah ekonomi, masalah kesibukan, masalah perselingkuhan, dan jauh dari agama.

Pertama, Komunikasi adalah proses pertukaran makna guna melahirkan sebuah pengertian bersama dalam suatu keluarga. Sebuah komunikasi dapat dikatakan terjadi bila dua belah pihak atau lebih yang terlibat dalam komunikasi mencapai pemahaman bersama. Komunikasi dapat dikatakan sukses bila masingmasing pihak membagi makna yang sama. Dengan komunikasi akan melahirkan pertautan perasaan atau emosi yang kuat diantara mareka yang terlibat, karena itu guna meraih kebahagiaan keluarga, sebaiknya komunikasikan berbagai peristiwa penting yang dialami dalam keseharian agar masing-masing pihak semakin mengenal dunia masing-masing dan merasa dilibatkan dalam dunia satu dengan dunia yang lain. Keluarga tanpa komunikasi bukan saja dapat menyebabkan kesalah

${ }^{20}$ Dedi Pahroji "penyelesaian sengketa mengenai hak milik serta bagian anak angkat dalam wasiat wajibah" jurnal ilmiah hukum de jure: kajian ilmiah hukum, Vol 1 No 2 (2016). 
pahaman, namun juga saling menjauhkan dunia masing-msing, sehingga akan Nampak jarak yang semakin lebar diantara satu anggota dalam suatu keluarga.

Kedua, Sikap egosentrisme, adalah sikap yang menjadikan dirinya pusat perhatian yang diusahakan oleh seseorang dalam hal ini adalah salah satu anggota keluarga (bisa ayah atau ibu) dan dilakukan dengan segala cara untuk mendapatkan perhatian tersebut. Pada seseorang yang memiliki sifat seperti ini, orang lain tidaklah penting, dia mementingkan dirinya sendiri, dan bagaimana menarik perhatian pihak lain agar mengikuti minimal memperhatikan. Akibat sifat egoisme ini orang lain sering tersinggung dan tidak mau mengikutinya. Misal seorang ayah tidak mau membantu ibu untuk menemani anak nya yang masih kecil, sementara ibu sedang sibuk di dapur, alasan ayah karena mau olah raga, akibatnya ibu marahmarah kepada ayah dan ayahpun membalas dengan kemarahan pula, terjadilah pertengkaran antara ayah dan ibu dihadapan anak- anak. Hal ini akan berdampak pada anak, misalnya anak membandel, sulit untuk disuruh dan suka bertengkar dan lain-lain. Sikap anak yang demikian ini adalah sebagai letupan emosional karena kondisi yang tidak menentramkan dalam keluarga akibat ulah orang tua atau sikap ayah dan ibu yang egosentrisme, atau dapat berdampak pada anak sehingga si anak menjadi pendiam, tertekan melihat kondisi atau sikap orang tua yang tidak bisa membuat tentram bila tinggal di rumah, yang lebih berbahaya lagi apabila anak lari atau mencari tempat yang nyaman di luar rumah dan lain sebagainya.

Ketiga, faktor ekonomi berperan sebagai upaya dalam membebaskan keluarga dari keadaan kemelaratan atau kekurangan dari kebutuhan yang diperlukan setiap hubungan perkawinan. Dengan keadaan ekonomi yang cukup atau tinggi bagi keluarga akan dapat hidup sejahtera dan tenang. Dalam mengatur ekonomi keluarga agar kebutuhan masing-masing keluarga terpenuhi, maka harus mampu memilah dan memilih antara kebutuhan primer dan kebutuhan sekunder 
serta kebutuhan pelengkap lainnya. ${ }^{21}$ Masalah ekonomi, tentang ekonomi ada dua jenis penyebab krisis keluarga, yaitu kemiskinan dan pola gaya hidup.Kemiskinan jelas berdampak terhadap kehidupan sebuah keluarga, sebagai misal jika karena faktor kemiskinan yang menyebabkan terjadinya krisis keluarga jelas, bagaimana mungkin jika terbatas dalam hal pendapatan lalu dapat mencukupi kebutuhan hidup suatu keluarga, tetapi ini juga masih bersifat relative, tergantung bagaimana memaknai “cukup' minimal standar hidup layak. Jika kehidupan suatu keluarga dimana kondisi emosional antara suami dan istri tidak cukup dewasa dalam menyikapi persoalan dalam kehidupannya maka akan selalu timbul pertengkaran yang disebabkan karena faktor ekonomi. Berbagai upaya pemerintah untuk menyelesaikan atau mengentaskan kemiskinan tetapi selalu ada kendala dan sulit untuk menjangkau si "miskin". Salah satu program pemerintah misalnya BLT (Bantuan Langsung Tunai) tahun 2007 dan 2008, yang tujuannya adalah untuk mengentaskan si miskin agar dapat hidup layak atau terpenuhinya standart hidup layak, tetapi justru jumlahnya semakin bertambah. Kedua, karena pola gaya hidup, kemiskinan yang seperti ini dapat dikatakan kemiskinan yang terselubung, misalnya untuk memenuhi standar hidup layak dalam arti normal belum tercukupi tetapi pola dan gaya hidup individu yang termasuk kategori ini sudah menunjukkan seperti orang kaya, atau mengikuti pola dan gaya hidup orang kaya. Ciri yang kedua ini bisa dikarenakan mindset atau kerangka pikir seseorang hal inilah yang perlu dirubah, masyarakat saat ini cenderung pada pola yang kedua. Ada berbagai faktor mengapa demikian? Pertama sebagai dampak arus modernisasi, filosofi yang berkembang adalah hedonisme dimana setiap manusia memuja pada kesenangan yang bersifat materi positifistik dan berjangka pendek, disisi lain jika tidak mengikuti pola yang demikian akan terisolasi dari lingkungan dimana ia tinggal. Hal inilah yang perlu dirubah,karena dengan mengikuti pola hidup yang demikian cenderung tidak ada pegangan atau prinsip hidup yang kurang jelas, sehingga

\footnotetext{
${ }^{21}$ Moch Afandi "hukum perceraian di Indonesia: studi komparatif antara fiqih konvensional, UU kontemporer di Indonesia dan negara muslim perspektif HAM dan CEDAW, jurnal hukum keluarga Islam, Vol 7 No 2 (2017)
} 
kehidupan suatu keluarga akan mudah terombang-ambing, seperti sebuah perahu yang berjalan tanpa arah bagimana bisa mendayung sampai ke tujuan.

Keempat, Masalah kesibukan. Kondisi orang tua yang sibuk baik suami atau istri dapat menyebabkan terjadinya krisis dalam keluarga, terutama masyarakat perkotaan kesibukan adalah ciri yang paling menonjol, hal ini tentu terkait dengan pencarian materi yaitu harta dan uang. Falsafah kehidupan sebuah keluarga telah berubah yaitu waktu adalah uang dan uang adalah harga diri, dan jika sudah kaya adalah suatu keberhasilan yang akhirnya adalah jabatan. Padahal ukuran kebahagiaan bukanlah uang sebagai patokan, justru yang demikian banyak terjadi keluarga yang berusaha dan bekerja keras tetapi belum juga berhasil seperti yang diharapkan, justru akan membuat frustasi atau kecewa berat akibat gagal dalam ekonomi suami istri dapat berakhir dengan bunuh diri. Makna kesaksesan hidup tedaklah semata-mata berorientasi pada materi.

Kelima, Masalah pendidikan. Pendidikan seringkali menjadi pemicu dalam permasalahan keluarga, seperti misalnya jika si suami atau istri pendidikannya rendah tentu wawasannya juga terbatas, tidak mengerti tentang liku-liku kehidupan sebuah keluarga, apalagi jika ada persoalan dalam keluarga dan ada turut campur mertua baik dari pihak suami atau istri maka persoalannya semakin rumit. Sebaliknya suami atau istri yang berpendidikan cukup tentu wawasannya juga luas, sehinga persoalan-persoalan yang muncul dalam kehidupan sebuah keluarga cenderung mudah mencari solusi dan persoalan cepat teratasi.

Hal ini sejalan dengan wawancara yang dilakukan peneliti dengan Hakim Pengadilan Agama Karawang Bpk Ahmad Hakim, SH.,MH pada tgl 20 Agustus 2019 yang menyatakan bahwa sebagian besar perceraian diakibatkan karena rendahnya pendidikan pasangan suami istri yang dominanya berpendidikan SMA/sederajat sebesar $70 \%$.

Keenam, perselingkuhan merupakan faktor yang berasal dari eksternal, faktor penyebab adanya perselingkuhan terjadi dalam hubungan perkawinan karena keadaan ekonomi dan krisis akhlak. Pengetahuan tentang agam yang kurang serta 
pemahaman menganai hak dan kewajiban diantara suami dan istri. Pemahaman tersbut membuat mereka tidak mengerti tentang tujuan terjadinya perkawinan . mereka memandang bahwa tujuan dari perkawinan semata-mata untuk memenuhi kebutuhan biologis tanpa memperhatikan pada tujuan yang bersifat ibadah ${ }^{22}$.

Tentang perselingkuhan termasuk masalah yang paling rumit untuk dikaji. Ada beberapa faktor yang menyebabkan terjadinya perselingkuhan, pertama, hubungan suami istri yang sudah hilang kemesraan dan cinta kasih. Hal ini berhubungan dengan ketidakpuasan seks, istri kurang menarik ketika di rumah, berdandan jika mau pergi sehingga sering menimbulkan kebosanan sang suami ketika di rumah, atau karena ada faktor kecemburuan baik secara pribadi maupun hasutan. Kedua, tekanan pihak ketiga seperti mertua dan lain-lain ( anggota keluarga lain) dalam hal ekonomi. Ketiga, adanya kesibukan masing-masing baik suami ataupun istri sehingga rumah bukan tempat yang nyaman untuk tinggal.

Hal inipun sejalan dengan pernyataan Bpk. Ahmad Hakim, SH.,MH yang menyatakan perselisihan ini terjadi karena adanya perselingkuhan yang dilakukan oleh salah satu pihak suami/istri yang mana hal tersebut menyebabkan faktor perselisihan menjadi determinan dominan dalam kasus perceraian selama periode 2017\&2018 dengan total keseluruhan kasus 2.084 kasus perselisihan dalam perceraian.

Ketujuh, Jauh dari agama. Islam mengajarkan kepada manusia untuk berbuat baik dan menjauhi atau melarang berbuat keji atau mungkar, sebagaimana difirmankan Allah dalam surat Al-Imron 110 Yang artinya: kamu adalah umat terbaik yang dilahirkan untuk ummat manusia, menyuruh kepada yang makruf dan

${ }^{22}$ Candra Hyatul Iman “ peran pemerintah daerah sebagai pengemban tanggung jawab perlindungan hak-hak anak dalam mewujudkan kota layak anak di kabupaten karawang: jurnal ilmiah hukum de jure kajian ilmiah hukum, Vol 2 No 1 (2017) 
mencegah dari pada yang mungkar serta beriman kepada Allah SWT...." 23 dalam menjalankan bahtera rumah tangga adakalanya terjadi perselisihan dan konflik yang terjadi antara suami dan istri. Menurut ajaran islam, bahwa perceraian merupakan sesuatu yang diperbolehkan tetapi sangan dibenci oleh ALLAH SWT. Jal tersbut menunjukan bahwa ikatan perkawinan yang telah terjadi jangan sampai berakhir atau putus karena perceraian. ${ }^{24}$

\section{PENUTUP}

Determinan yang mempengaruhi perceraian di Pengadilan Agama Karawang periode 2017-2018 adalah: meninggalkan salah satu pihak sebanyak 1.005 kasus , perselisihan terus menerus sebanyak 2.084 kasus, faktor ekonomi sebanyak 1.525 kasus dan tidak ada keharmonisan dalam rumah tangga sebanyak 968 kasus.

Determinan dominan yang mempengaruhi perceraian di Pengadilan Agama Karawang periode 2017-2018 adalah perselisihan terus menerus sebanyak 952 pada tahun 2017 dan 1.132 pada tahun 2018. Hal ini sejalan dengan salah satu faktor yang mempengaruhi perceraian dalam Pasal 116 Kompilasi Hukum Islam huruf F "Antara suami dan isteri terus menerus terjadi perselisihan dan pertengkaran dan tidak ada harapan akan hidup rukun lagi dalam rumah tangga”.

\footnotetext{
${ }^{23}$ Sofyan wilis, faktor-faktor perceraian dalam rumah tangga, Jakarta: rieneka cipta 2009. Hlm 30 .

${ }^{24}$ Nunung Rodiliyah “akibat hukum perceraian berdasarkan UU No 1 tahun 1974 tentang perkawinan" keadilan progresif, jurnal ilmiah hukum Vol 5 No 1 (2014)
} 


\section{DAFTAR PUSTAKA}

\section{A. BUKU}

Abd rahman ghazali, fiqih muamalah, prenada media, Jakrta: 2003

Honny Ibrahim, Teori dan Metodologi Penelitian Hukum Normatif, Bayumedia Publishing, Malang, 2006,

Iskandar, Metodologi Penelitian Kualitatif, Gaung Persada , cet.1, Jakarta, 2009.

Soerjono Soekanto dan Sri Mamudji, Penelitian Hukum Normatif Tinjauan Singkat, Rajawali Pers, Jakarta, 2006.

Sofyan wilis, faktor-faktor perceraian dalam rumah tangga, Jakarta: rieneka cipta 2009.

Subekti ,Kitab Undang-Undang Hukum Perdata,Pradnya Paramita, Jakarta, 2004.

Sujuti Talib,Hukum Kekeluargaan Indonesia, Universitas Indonesia press, Jakarta, 1982.

Tan Kamello dan Syarifah lisa Andriati, Hukum Orang dan Keluarga, USU Press, Medan, 2011.

Wirjono Projodikoro, hukum perkawinan di Indonesia,cetakan keenam.

Zainul Bahri, Kamus Umum Khusus Bidang Hukum Dan Politik, Bandung, Angkasa, 1993.

\section{B. JURNAL ILMIAH}

Candra Hyatul Iman " peran pemerintah daerah sebagai pengemban tanggung jawab perlindungan hak-hak anak dalam mewujudkan kota layak anak di kabupaten karawang: jurnal ilmiah hukum de jure kajian ilmiah hukum, Vol 2 No 1 (2017)

Dedi Pahroji "penyelesaian sengketa mengenai hak milik serta bagian anak angkat dalam wasiat wajibah" jurnal ilmiah hukum de jure: kajian ilmiah hukum, Vol 1 No 2 (2016).

Dian Ety Mayasari, tinjauan yuridis adanya KDRT sebagai alasan untuk melakukan perceraian" MIMBAR HUKUM jurnal.ugm.ac.id Vol 25, No 3 (2013) 
Elsa Cholidatul Nikmah "batasan alasan perceraian karena perselisihan dan pertengkaran secara terus menerus (studi pasal 116 huruf F kompilasi hukum islam)" hukum student journal 2018.

Husin anang kabalamay " kebutuhan ekonomi dan kaitannya dengan perceraian (studi atas cerai gugat di pengadilan Agama Ambon) jurnal IAINAMBON Vol 3 No 2 (2013).

M. Rampto laguni “ tinjauan yuridis terhadap perselisihan terus menerus sebagai penyebab terjadinya perceraian (studi putusan Pengadilan Agama Palu Bo 334/Pdt.G/2013/PA.PAL)" jurnal ilmu hukum Legal Opinion edisi 6, Vol 1 (2013)

Moch Afandi "hukum perceraian di Indonesia: studi komparatif antara fiqih konvensional, UU kontemporer di Indonesia dan negara muslim perspektif HAM dan CEDAW, jurnal hukum keluarga Islam, Vol 7 No 2 (2017)

Nunung Rodiliyah “akibat hukum perceraian berdasarkan UU No 1 tahun 1974 tentang perkawinan" keadilan progresif, jurnal ilmiah hukum Vol 5 No 1 (2014)

Syaefullah " tidak ada keharmonisan sebagai penyebab perkara cerai gugat di kota kediri” jurnal iainKediri Vol 1 No 1 (2017)

Ummul khaira, pelaksanaan upaya perdamaian dalam perkara perceraian,. FH Universitas Syiah Kuala. Jurnal Penelitian Hukum De Jure Vol.18, No 3. (2018).

\section{PERATURAN PERUNDANG-UNDANGAN}

Kitab Undang-Undang Hukum Acara Perdata

Undang-Undang Nomor 1 Tahun 1974 Tentang Perkawinan;

Kompilasi Hukum Islam Intruksi Presiden R.I. Nomor 1 Tahun 1991

\section{INTERNET}

Kamus Bahasa Indonesia

https://www.bps.go.id/linkTableDinamis/view/id/893 (5/8/19. 12:23)

https://jabarnews.com/read/70157/kasus-perceraian-di-jawa-barat-meningkat $(5 / 8 / 19.11: 10)$ 